Article

\title{
From Schnitzel to Sustainability: Shifting Values at Vienna's Urban Farmers Markets
}

\author{
Milena Klimek ${ }^{1, *}$, Jim Bingen ${ }^{2,+}$, Bernhard Freyer ${ }^{1}$ (D) and Rebecca Paxton ${ }^{3,4}$ \\ 1 Division of Organic Farming, Department of Sustainable Agricultural Systems, University of Natural \\ Resources and Life Sciences, 33 Gregor-Mendel Straße, 1180 Vienna, Austria; Bernhard.freyer@boku.ac.at \\ 2 Department of Community Sustainability, Michigan State University, Natural Resources Building, \\ East Lansing, MI 48824, USA; bingen@msu.edu \\ 3 School of Humanities, The University of Adelaide, North Terrace Campus, Adelaide, SA 5005, Australia; \\ rebecca.paxton@adelaide.edu.au \\ 4 Centre for Deliberative Democracy and Global Governance, University of Canberra, \\ Canberra, ACT 2601, Australia \\ * Correspondence: milena.klimek@boku.ac.at \\ + This author has retired.
}

Citation: Klimek, M.; Bingen, J.; Freyer, B.; Paxton, R. From Schnitzel to Sustainability: Shifting Values at Vienna's Urban Farmers Markets. Sustainability 2021, 13, 8327. https:// doi.org/10.3390/su13158327

Academic Editor: Michael S. Carolan

Received: 1 June 2021

Accepted: 22 July 2021

Published: 26 July 2021

Publisher's Note: MDPI stays neutral with regard to jurisdictional claims in published maps and institutional affiliations.

Copyright: (c) 2021 by the authors. Licensee MDPI, Basel, Switzerland. This article is an open access article distributed under the terms and conditions of the Creative Commons Attribution (CC BY) license (https:// creativecommons.org/licenses/by/ $4.0 /)$.
Abstract: This paper presents an empirically grounded investigation of the values and practices of farmers markets (FM) in Vienna, Austria and their linkages to wider alternative food practices of ecological, social and economic sustainability. If the FMs are to play a vibrant role in the Viennese alternative food system, enhancing urban-rural connections and urban resilience, they must re-align their values to this system. A values-based conceptual framework is used to examine the structures and functions of six Viennese FMs and the alignment of values and practices among FM managers, farmers/vendors and consumers. Data from qualitative interviews, participant observation and dot surveys were collected at each FM. Value alignment is discovered as necessary to support and perpetuate alternative values. Governance is found to be significant for aligning values related to FM sustainability. Current structures and functions of Viennese FMs cannot be easily aligned with participant values and practices. As one of the first examinations of Viennese FMs, this work illustrates concrete challenges, priorities and emphasizes the role that governance and social organizing plays in successful markets as contributors towards sustainable urban food systems. Lessons learned can be applied to municipal FMs and other food system actors that face similar challenges.

Keywords: farmers markets; Vienna; Austria; values; sustainable urban food systems; alternative food systems; governance

\section{Introduction}

As societies become increasingly urbanized, farmers markets (FMs) in metropolitan food systems are in a position to contribute to sustainable development goals. FMs help simplify and localize food production, bring together regional farmers/vendors and consumers and assist in building local economies based on shared values [1]. In doing so, they can both increase trust through direct consumer producer relationships, and enable a more resilient and adaptive food system in times of crises-such as the current COVID-19 pandemic and other food system disturbances [2]. FMs also help to steer food system values and practices away from commercialized and industrialized standards [3] through the creation of alternative communities of consumption [4]. They serve as sites for sharing alternative values and practices, such as those of the organic farming movement because they may bring attention to a range of health, environmental, fairness and care values (See: $[5,6])$. FMs are therefore a conspicuous contributor to, and often the cornerstone of, urban alternative food systems (AFS).

AFS describes a system of self-organized agro-food networks often geographically based around a city or state, focused on the rise of sustainable and "alternative food 
practices that emerged in the 1990s as a reaction against the standardization, globalization, and unethical nature of the industrial food system" ([7] p. 1)AFSs offer innovative urban-rural linkages often related to direct marketing of farm products. "Common examples include community supported agriculture, farmers' markets, fair trade, urban agriculture, specialized forms of organic agriculture, direct farm retail, and the slow food movement" ([7] p. 1). They are seen as contributors in the transition towards sustainable food system pathways [1], particularly due to their solidary habits [8], making many AFS practices more economically, environmentally, and socially sustainable than conventional food systems [9].

As one of the most popular AFSs, FMs especially have the ability to publicize the alternative and sustainability values of AFSs.

To better grasp how values are aligned within FMs, we examine the structures and functions of FMs in Vienna, Austria and the values and practices of their participants. 'Value alignment' is defined here as an alignment of the FM's structures and functions with the values and practices of its participants. A farmers market structure describes the arrangements necessary for its operation. It comprises the participants, finance, ownership, the community in which it is embedded, and particularly its governance-i.e., the decision makers and management. A farmers market function includes its overall purpose, often comprising a mission (whether explicit or implicit). We use a values-based conceptual framework to identify, organize and analyze values found and their alignment among and between the three main FM participant groups-managers, farmers/vendors and consumers.

At first glance, markets in Vienna bustle with interested consumers and booths apparently filled by farmers. However, in contrast to FMs elsewhere (In the past 20 years popularity and numbers of FMs have greatly increased in North America, Great Britain and Austral-Asia [10,11]), the actual farmer/vendors in Vienna have had both their time and allocated spaces reduced. The number of farmer vendors has also declined as resellers have been allowed to replace them $[12,13]$. The Viennese FMs are challenged with further disengagement of actual farmers and producers as vendors, or making fundamental changes to FM structures and functions towards a resurgence of farmer-vendors. FMs elsewhere have prioritized participant values alternative to traditional FMs and conventional supermarkets-embedding them in their AFS. Integration of the Viennese FMs into its respective AFS may be a way to revitalize Viennese FMs as it has been for FMs elsewhere.

This article examines the values of FM managers, farmers/vendors and consumers in FMs of Vienna, and argues that aligning the values of FM participants with their structures and functions is central to the development of, and contribution to a resilient urban food system and to food system transformation. Shared values among key actors, and a community that supports such values, are necessary if enduring and genuinely sustainable agri-food systems are to be created [14]. We hypothesize that misaligned values at these FMs hinder their contribution to the Viennese AFS.

The aim of this paper is twofold: (1) to diagnose the current structures and functions of Viennese FMs at the crossroads between the city's conventional and alternative food systems; (2) to identify priorities to challenges for aligning the FMs structures and functions with the values of key participants. By doing so, we hope to improve the resilience and sustainability of Viennese FMs by linking them to their AFS.

Acknowledging the ecological and social benefits of AFSs-particularly illustrated here through FMs-and improving upon their pitfalls is a step toward creating a resilient and decentralized food system. The results suggest how the Viennese and other municipally governed urban FMs might respond to the changing values and practices of their participants. This research offers a roadmap for market managers, policy makers and consumers to integrate traditionally structured municipal FMs' into alternative and sustainable food systems. 


\section{Farmers Markets at a Glance}

\subsection{Farmers Markets: From Tradition to Platforms for Values of Social, Ecological and Economic Sustainability}

As in many Western European countries, Viennese FMs are embedded within the municipal public market system and reflect their long histories and traditions $[15,16]$. FMs were founded through small-scale, periodic, and often producer-level exchange. As they became more popular and expanded in size, they became less temporary and were structured through governmental regulation, particularly regulating safety and hygiene, space for procurement and citizen accessibility. They were "established by political authorities, such as municipalities" and their functions were "to provision an urban population" ([17] p. 172). With improved infrastructure, transportation, and refrigeration, most traditional FMs were largely replaced by supermarket chains. In contemporary Vienna, however, FMs as part of public markets still serve as spaces for everyday food procurement [18], and they include a mix of farmer and reseller vendors who seek to offer their products at inexpensive prices, often competing with supermarkets [19].

Following a decline during the 1950 and 60s, the resurgence and popularity of FMs has been attributed to a growing consumer and producer interest in AFSs that promote values related to economic, ecological, and social sustainability [20]. These values include trust, product quality and health, re-localization of the food system, small farmer support, and ecological and community sustainability [20-25]. In response to these demands, 'contemporary' or 'mission oriented' FMs have departed from their traditional predecessors by emphasizing the role of alternative values. Traditionally, FMs were simply viewed as "... [an] area where multiple growers gather on a regular basis to sell a variety of fresh fruits, vegetables, and other farm products directly to customers" ([26] p. 7). In contrast, contemporary FMs tend to include a mission statement, or purpose, which outlines the markets' functions and decision-making structures, fosters participant values through direct exchanges between consumers and farmers, and promotes shared values by FM management [27].

As key players in AFSs and local economies, FMs rely heavily on the interplay between the values of three key participant groups: market managers, farmers/vendors and consumers. The communication and sharing of values among and between these participants occurs at varying levels of success at different markets. Modern FMs can stimulate community education and awareness by fostering the shared alternative values and practices of consumers and farmers/vendors [28]. Shared values within FMs build community by attracting like-minded participants, contributing to the economic and social success and longevity of the markets [4,29], and providing opportunities for local businesses in a farmers markets's vicinity [30]. In short, the presence of these values and practices helps to define a particular FM as a cornerstone of their AFS.

For this article, we see the values and practices within the Viennese FMs as primarily conveyed through their purpose, governance, and participants (See: [31]). This permits us to identify influences that lead to the expression or absence of such values and practices and their alignment.

\subsection{The Role of Purpose, Governance and Participants in Shared FM Values}

A purpose reflects the function of an FM. In contemporary FMs, purposes are often illustrated through mission statements. Contemporary FMs are socially constructed networks that connect producers and consumers who are concerned with the reorganization of values, morals, and the ecological sustainability and quality of food production and consumption [27]. These "New Generation" FMs emerged over the last thirty years as actors in AFSs and as possible gateways to other food systems innovations and marketing opportunities [32,33]. They emphasize "farmer only markets" or FMs that mainly accommodate farmers/vendors [33]. Such FMs are often structured as public partnerships between cities and farmers or private partnerships between nonprofits or neighborhood organizations and farmers [34]. This recent type of governance structure encourages FMs to 
be mission-oriented with a purpose related to health or environmental and social concerns that are attractive to consumers $[35,36]$. These alternative values are practiced through direct contact with, and support of, producers [37]; visibility in a community as opposed to the often, anonymous commercialism of supermarkets [38]; product freshness and healthfulness [36], community, education, and market ambience [27]; and attempts to rebuild more localized and ecologically sustainable food systems [28,39]. Consequently, such values in FMs create alternative or issue-driven communities of consumption' $[4,40]$ that allow for direct marketing and local innovations that can enhance urban resilience and distinguish the values and practices of such FMs from supermarkets.

Mission-oriented markets allow for a community to share and build upon existing values and create a common market vision. Successful FMs frequently elaborate a clear and encompassing purpose [34], and the more consumers and farmers that identify with the mission, the more successfully the market can be managed [41]. A clear purpose frequently activates the optimization of FM structures supporting the direction of their purpose, creating a sort of causal loop. The reflection of a FMs' functions and structures to the values and practices of its participants, then influences a FM's impact-longevity and authenticity - within their surrounding AFS, often increasing social innovation related to such values [40].

How decisions are made and who makes them contributes to the way a farmers market is run, and the values and practices that ensue. Shared interests are often furthered by market managers and governance structures put in place to strengthen the community and its economic goals [42]. Betz and Farmer [43] state it is "... what emerges as a result of the governance that affects market characteristics and consequently the consumers and the experience" (11). Market managers often construct and influence how FMs operate in pursuit of their mission, while consumers and farmers/vendors chiefly employ values and practices that inform FMs' missions or purpose [44]. In contemporary FMs, " ... managers act as liaisons between the community, advertisers for the farmers, and planners for the market and other related events" ([45] p. 8). Therefore, FM governance can have a strong influence on an FM's projected (not necessarily applied) values and practices through its management and decision-making structure [34]. Capitalizing upon common values and other social gains at FMs, particularly through management, has proven beneficial for sales volume [46], positive for local economies [47], and strategic in creating healthy communities [48].

The community in which a farmers market finds itself and fosters is not only the place in space and time in which the FM resides, but it is also composed of its key participants and is enhanced through their shared values and practices. The market manager, farmer/vendors and consumer participant groups are essential for, help make up, and are part of a farmers market. The cooperation and combined reflexivity of these participants encourage collaborative learning, crucial in sharing and creating shared values [14,49], and contribute to "stakeholder autonomy and empowerment, collaborative governance, and transformative leadership", essential characteristics on the path towards urban sustainable change ([40] p. 129).

Following an explanation of the methods used, the existing Viennese FM system is described and conceptualized through their market structures and functions, and participants. The findings are then discussed using areas of priorities: purpose, governance and participants to identify the potential of shared (aligned) values among participants for improving current FM conditions, integration in their AFS, and ultimately urban sustainability. It highlights specific features of the Viennese case that may be helpful for other metropolitan or municipally run FMs with similar structures and functions.

\section{Materials and Methods}

This investigation was part of a larger cross-national study conducted from 2012 to 2016 that compared the role of values in FMs [50]. 
Six of Vienna's 22 markets were selected as cases for this research. The selected markets represent a range of sizes, operating times, popularity, and number of actual farmers as vendors. Data were collected from managers, farmer/vendors and consumers at each of these markets, to gain a holistic understanding of the structures and functions of Viennese FMs, and the values and practices of their participants. This allowed us to compare findings across participant groups as well as across markets.

All empirical data collection was guided by a values-based framework, which draws on the operations, logistics, structure and values of each market. The framework was created by adapting two approaches that are particularly suitable for exploring the structure and function of FMs. First, the concepts of Purpose, Governance, Participants, Finance and Marketing, and Community were drawn from the Generative Ownership principles [for more a more in-depth description of these principles, (See [31]). The second approach that was adapted for this study, is Garry Stephenson's Agro-Social-Economic Regulatory Ecology of FMs. Specifically, this research draws on Stephenson's description of features that are specific to FMs, namely atmosphere (See: [42]). Additionally, the Organic Principles-Health, Ecology, Fairness and Care-were included as representative of the values underpinning alternative food production (See: the International Federation of Organic Agriculture Movements (IFOAM) [51]). These combined principles, comprise a values-based analytical framework, which we used to examine FM structures, functions, and participant values (see [50]). In this paper, particularly the principles of purpose, governance and participants were integral for comparing the structures and functions of Viennese FMs, and the values and practices of their participants, with those present in modern FMs (as seen in the structure and subsequent literature of the previous section).

To obtain a picture of the Viennese FMs, a literature review, interviews, participatory observation, and dot surveys were conducted; these offered both quantitative and qualitative data and enabled direct engagement with the participants. The qualitative interviews generated a descriptive representation of market structures and functions, values of both the managers and producers, and their perceptions of consumers. For each FM, at least one manager and two farmers/vendors were interviewed, providing 23 in-depth, semi-structured interviews. As we were primarily interested in the values and practices of farmer vendors rather than resellers, $88 \%$ of the interviewed vendors were farmers. The remainder were resellers who were recommended by market managers due to their high level of engagement both within the FMs and with the producers of the products they sold. Interview partners were obtained largely thorough a snowball method beginning with suggestions made by market managers. Although this study does not claim to be representative, it is worth mentioning that the number of actual farmer/vendors at the FMs is low. For example, at the Victor-Adler market, of the 50 FM stands, only five were actual producers. Finally, the values-based framework influenced the interviews' structure and coding process and were analyzed using the qualitative data analysis software Atlas.ti, Berlin, Germany.

Dot-surveys conducted at each Viennese FM during the summer of 2014 helped to elucidate consumer views (See Table 1). Dot surveys typically ask 4-5 closed-ended questions, which respondents answer by marking their preference on a flipchart with a 'dot' sticker for each question. If desired, participants may be given different colored stickers, corresponding to a demographic or other relevant variable (See: [52]). Although dot surveys are a common market research method in the US, we found no evidence that it has previously been used in FMs in Austria. Although they have traditionally been used by market managers to understand consumer preferences, demographics, and opinions, we used dot surveys to examine consumers' values and practices.

In total, 1490 people participated in the dot surveys across the six Viennese FMs (see Table 1). Each survey took place during the 3-4 most frequented hours on a single market day. The survey respondents were offered different colored dot stickers to indicate their gender identity. The survey questions drew upon other FM consumer research and addressed contemporary FM values and practices (See: [22]). The dot survey questions and 
response options were developed in collaboration with market managers, in accordance with the participatory nature of the larger study. The following five questions were asked (to find the questions and the possible answers to choose from in full, please see Supplementary Material 1 information): (1) How often do you come to this farmers market? (2) What is the main reason you come to a farmers market? (3) What one feature would make you come to this farmers market more often? (4) What one activity would you most prefer to enhance the farmers market atmosphere (5) What one feature do you think would further support farmers at farmers markets?

Table 1. Number of dot survey participants at each of the six markets examined. $\mathrm{F}=$ female and $\mathrm{M}=$ male.

\begin{tabular}{ccccccc}
\hline Market & Nasch-Markt & Kutschker-Markt & Viktor-Adler-Markt & Brunnen-Markt & Karmeliter-Markt & Bio-Freyung \\
\hline $\begin{array}{c}\text { Number of } \\
\text { Participants }\end{array}$ & 148 & 296 & 192 & 500 & 248 & 104 \\
\hline
\end{tabular}

Finally, participatory observation by volunteering and through numerous shopping trips to each market provided the opportunity to observe market days in their entirety, as well as interactions of farmer/vendors and consumers. Participant observation also helped to build rapport with the managers, farmer/vendors, and consumers and corroborate their interview/survey responses. A field journal from these observation days, was also coded via the values-based framework.

\section{Results}

The following section presents the study findings based on analysis of the empirical data collection related to the first aim of the paper. The current structures and functions of the six Viennese FMs are outlined, followed by the identified values and practices of each FM participant group. The shared and conflicting values and practices of market managers, farmer/vendors and consumers are compared to identify opportunities and challenges to greater value alignment, and address the second aim of the paper.

\subsection{Structure and Functions of the Viennese Markets}

Interviews with market managers and farmers/vendors highlighted how the long history of Viennese FMs affects their current structurers and functions. A brief outline of that history and its relevance for the current structures and functions is provided below.

Like many European public markets, the Viennese markets date from the beginning of the seventeenth century. These early markets were temporary with farmers and resellers displaying wares in baskets or on the ground [53]. As they became the predominant spaces for food procurement, permanent infrastructure was built. These current markets have been in the same place for hundreds of years, generating a sense of permanence which cements them in the 'common knowledge' of the city.

In 1839 the city of Vienna created the Market Bureau to centralize market management and regulation [54]. Both the space allocated for the market, as well as the managers and other market staff (from administration to cleaning personnel), are government positions. The city protects historical institutions; therefore, FMs are safeguarded by a reliable annual budget. As the FMs are part of larger public markets, the Market Bureau takes care to regulate fair pricing of products and provide a safe environment for consumers by conducting routine food safety and hygiene inspections. However, FMs themselves have a limited set of rules and income for the municipal Market Bureau, and thus receive less management attention.

The market managers described the structures and functions of the FMs as encompassed by the broader public markets. All of Vienna's 22 public markets are managed and governed by the city of Vienna which hosts a website that briefly describes each market's history, its days/hours of operation, and roughly the products available. The functions of these markets are defined by the Market Bureau's goals, which are to offer access to safe and hygienic food to the citizens of Vienna. Most of these markets have permanent infras- 
tructure for resellers and cafes, but only limited space for the temporary farmer/vendor stands. Market buildings typically house one or two vendors and have electricity and running water; some of the cafes have bathrooms.

Fourteen public markets still include temporary stands that sell fresh produce, meats, cheeses, baked goods, honey and wine. This area in a market is called the Landparteienplatz-known as the "farmers market". We examined six (See: Table 2).

Table 2. The 6 Viennese FMs examined.

\begin{tabular}{|c|c|c|c|c|c|c|}
\hline $\begin{array}{l}\text { Farmers } \\
\text { Market (FM) } \\
\text { Name }\end{array}$ & Description & Vendors & $\begin{array}{l}\text { Days } \\
\text { Public } \\
\text { Market } \\
\text { Open }\end{array}$ & $\begin{array}{c}\text { Days } \\
\text { FM Open }\end{array}$ & $\begin{array}{l}\text { Approx. } \\
\text { Years } \\
\text { Running }\end{array}$ & $\begin{array}{c}\text { Size of } \\
\text { Market }\end{array}$ \\
\hline $\begin{array}{c}\text { Freyung } \\
\text { Organic } \\
\text { Bauernmarkt }\end{array}$ & $\begin{array}{l}\text { A temporary weekend plaza } \\
\text { market; organic certification is } \\
\text { required; an additional } \\
\text { association to regulate this } \\
\text { was formed creating } \\
\text { management autonomy from } \\
\text { municipal system; location is a } \\
\text { challenge as tourists aren't } \\
\text { interested in produce. }\end{array}$ & 20 FM stands & Fr-Sa & Fr-Sa & 25 years & Small \\
\hline Karmelitermarkt & $\begin{array}{c}\text { A plaza, niche market; } \\
\text { including organic and slow } \\
\text { food; numerous farmers and } \\
\text { producers; well-to-do clientele } \\
\text { of many ages and } \\
\text { many families. }\end{array}$ & $\begin{array}{l}30 \text { fixed * } \\
\text { stands approx. } \\
40 \text { FM stands }\end{array}$ & Mo-Sa & Fr-Sa & 345 years & Medium \\
\hline $\begin{array}{c}\text { Viktor-Adler } \\
\text { Markt }\end{array}$ & $\begin{array}{l}\text { A thriving street market; } 5 \\
\text { producers and } 50 \text { resellers; } \\
\text { competitive; immigrant } \\
\text { consumers buy inexpensive } \\
\text { bulk; challenges with product } \\
\text { diversity and } \\
\text { integrating organic. }\end{array}$ & $\begin{array}{l}75 \text { fixed stands. } \\
60 \text { FM stands } \\
\text { on street }\end{array}$ & Mo-Sa & Mo-Sa & 140 years & Large \\
\hline Kutschkemarkt & $\begin{array}{l}\text { A small street market; friendly } \\
\text { and personal, majority of } \\
\text { organic from farmers and } \\
\text { resellers, well-to-do families; } \\
\text { many children; high prices. }\end{array}$ & $\begin{array}{l}20-50 \text { fixed } \\
\text { stands approx. } \\
30 \text { FM stands }\end{array}$ & Mo-Sa & $\mathrm{Fr}-\mathrm{Sa}$ & 130 years & Small \\
\hline Naschmarkt & $\begin{array}{l}\text { Vienna's most well-known } \\
\text { and largest market; lots of } \\
\text { exotic foods and tourist items; } \\
\text { many resellers; small number } \\
\text { of farmers; Fridays host } \\
\text { organic selection. }\end{array}$ & $\begin{array}{l}120 \text { fixed stands } \\
\text { Approx. } 50 \text { FM } \\
\text { stands }\end{array}$ & Mo-Sa & $\begin{array}{l}\text { Mo-Sa; } \\
\text { most on } \\
\text { Fr-Sa }\end{array}$ & 235 years & Large \\
\hline Brunnenmarkt & $\begin{array}{l}\text { An exotic street market; } \\
\text { frequented by locals; colorful } \\
\text { and bazaar like; some } \\
\text { organic present. }\end{array}$ & $\begin{array}{l}120 \text { fixed stands } \\
\text { Approx. } \\
50 \text { FM stands }\end{array}$ & Mo-Sa & Fr-Sa & 185 years & Large \\
\hline
\end{tabular}

* Fixed stands are typically part of a public market's permanent infrastructure and are much larger than FM stands. ** Based on Stephenson's model of FM size (see [42]).

Farmers markets today occupy smaller spaces inside only some of the public markets. As a result, farmers play a decreasing role in Viennese markets. Several factors were described as influencing the declining number of farmer vendors. As the structures of the public markets have increased in value due to the addition of permanent infrastructure and amenities for more gastronomy, rents have also increased to levels that have started 
to preclude actual farmers and even resellers. In the past 50 years, farmland and garden space within and surrounding Vienna has decreased, and as a result, direct marketing by nearby farmers has declined [55]. Resellers and restaurants now operate numerous stands that were previously maintained by farmers.

In 2006, the Market Bureau streamlined market structure and regulations to follow a Cameralist (kameralistisch) operating system. This business strategy is common in Austria and it is similar to mercantilism with its heavy state involvement. It strictly separates state departments (e.g., the Market from the Agricultural Bureau) thereby making shared functions, communication and funding between bureaus difficult. The government hierarchy considerably limits the influence of individual market managers over their assigned market, and even the selection of vendors is done by lottery.

Managers regularly assess space in FMs for new vendor stands. Farmers take precedence in filling open spaces, followed by resellers and those selling items other than food. In addition to the assigned vendors, an even smaller area is left open for seasonal vendors-e.g., strawberry or asparagus farmers. Open spaces are allotted through the lottery system to vendors interested in selling at a particular market on that day. However, the practice of these Cameralist policies, particularly due to role separation in departments, are a more laissez-faire, hands-off management system that cannot actively advertise or hand-select vendors. As a result, many markets lack product and producer diversity, and transparency-i.e., clear delineation and signage between farmer and re-seller.

Both farmers and managers expressed that due to such vague signage and often nonexistent delineations, consumers are often unaware of the structural and functional difference between public markets and FMs. Despite the decline of farmer vendors, the term "farmers market" continues as the generic term. Managers shared that consumers often assume that the whole public market area is for farmers, and thus they continue to call it, mistakenly, the farmers market.

In late 2018, the market regulations were reviewed to 'simplify and de-bureaucratize' the markets. The markets are now separately permitted to decide specific opening times and the percent of restaurants and food stands within the limits of the Market Bureau's requirements. This allows some freedom to individualize markets catering to their neighborhood circumstances. However, the temporary farmers market area was not mentioned in these new regulations, confirming their small role.

Finally, a clear and direct way of communicating to the over two million inhabitants of Vienna (and its tourists) through a blog, app, community booth at the markets offering relevant education and participation beyond consumption, does not exist. This type of communication and advertisement falls on the shoulders of the farmers. However, managers confirmed that when marketing and communication becomes the farmers' responsibility, in addition to the many tasks of farming, many fail (see [28]).

\subsection{Participant Values and Practices of Viennese Farmers Markets}

\subsubsection{Managers}

As employees of the Market Bureau, managers view the function of a farmers market as the same as any other source of food procurement and the structures of the FMs are fashioned to reflect this view. Therefore, the market managers, and the governance system which they enforce do not collectively recognize FMs as an alternative to supermarkets or the industrialized food system. As a result, FMs are not distinguished from, and therefore compete with, other sources of food procurement.

The Market Bureau has undergone several organizational changes, but none have included a concrete mission statement that articulates market values and practices to its participants and the wider public. When specifically asked about the values that the FMs represent, or an existing mission statement, market managers were either confused (exhibiting inclinations towards traditional functions) —or referred to their role in providing access to safe and hygienic food to the citizens of Vienna. 
Despite attempts to invite more famers, regulations to avoid farmer/vendor favoritism, financial, and time constraints prevent managers from making changes to attract farmers. This has led to the self-justifying belief that "farmers do not want to spend the time and effort to drive every weekend to Vienna to sell" (Manager 5).

Some managers blame this on the difficulty in gaining cooperation among different governmental departments. Although they are not allowed to cultivate or advertise new, more modern consumer values, managers are aware of the implications of not doing so. Some considered mitigation through the benefits of a third party-e.g., an organization-to highlight alternative issues, farmer support and increased farmer participation, stating that such organizations " ... should be spreading knowledge to create awareness about such issues so that a customer can look over the facts and information" (Manager 3).

The FM managers are largely responsible for upholding existing market structures and functions decided upon by the Market Bureau. This holds true for every Viennese market, thereby unifying and perpetuating existing traditional values coming from these structures and functions, such as safety, hygiene, space for food procurement, access for all citizens, and hierarchical governance. However, managers mentioned the organic Freyung FM as an interesting outlier. The FM vendors formed an association with the additional purpose of selling exclusively organic products. This opened up opportunities to vote for internal leadership and created funds for awareness raising and community building activities. The managers also mentioned how "easy" this particular market was to manage, as the existing self-organization and internal communication buffers additional managerial tasks.

\subsubsection{Farmers}

Differing values and practices found among FM farmers can be described through two loosely defined groups of farmers identified as "traditional" or Quereinsteiger.

The traditional come largely from small farms and have typically been selling for generations. These farmers value the production of "quality products that are fresh" (Farmer 3)-distinguishing themselves from supermarkets. Many practices do not prioritize or exhibit an awareness of community building and related FM events as a way to further differentiate themselves. Distinguishing practices include traditional and conventional farming techniques and a pragmatic, "no bells and whistles" form of selling (business identity through signage or way of displaying wares is not a focus). They value the tradition of generations of market participation-building trust with their consumer base.

A strong sense of defeat could be felt among many of the traditional and often older farmers interviewed: "Small farms are dying out, soon there will not be any small farmers left" (Farmer 11). Many were certain that they would be the last generation working their farm and selling at the markets. These views were often accompanied by stories of children uninterested in farming, or worries about financial viability. Several farmers remember when more space was available and many more farmers sold throughout the week; " ... in the 80 s there was a drop in people coming to the market. They [the Market Bureau] closed half of the street to farmers" (Farmer 8). It remains closed today.

Finally, these farmers/vendors suggested that the Market Bureau could provide better stand and product storage, and parking opportunities to encourage more producer participation.

The second group represents a small but growing number of alternative farmers/vendors, encompassing many new or young, innovative food and farming entrepreneurs known as Quereinsteigers. Most practice organic methods have an interest in ecological and social sustainability and have changed careers to become producers. Within this group of relatively new FM participants, there is a more hopeful perspective: "Farmers markets are great instruments for small farmers" (Farmer 6). They expressed more connections to consumer values, as many shared similar values, and used contemporary techniques of vending: aesthetic stands, signage and the use of social media for promotion. They identified FMs as an alternative space for food procurement with the potential to distinguish values and practices that support such a view by applying contemporary market values, underlining their alternativeness from supermarkets, and practices that consumers find attractive. 
They often mentioned that the Market Bureau should play a larger role in distinguishing their alternativeness and advertising for, and raising awareness about producers: "We [farmers] need more support [from the Market Bureau] through marketing, advertising and education ..." (Farmer 5).

The actions of farmer/vendors at the organic Freyung FM exhibited a rather successful response in procuring additional formal leadership to that of the Viennese Market Bureau. The FM association formed with the additional purpose of selling exclusively organic products highlights the challenges of a farmers market system caught in the middle of two value systems-e.g., that of a more conventional food system approach and an alternative food system. It also gives examples of how they might coexist together while still contributing to their respective AFSs.

\subsubsection{Consumers}

Viennese FM consumers share values regarding product quality, support for farmers, ecological and social sustainability, and learning about the production and origin of their food. Consistent with other FM consumer data, the dot surveys revealed that the majority of Viennese FM shoppers are women and regular customers who purchase weekly.

There was an overwhelming interest of Viennese consumers across all FMs particularly for more farmer presence, specific information about products, and small farmer support. They also showed interest in wider availability of organic products at all markets (with the exception of the organic Freyung market) and larger variety of products, specifically at the Viktor-Adler, Naschmarkt and Freyung markets. The FM consumers lean toward promotion of regional, high quality products, seasonality, and showed strong ties to traditional cuisine. A great number of consumers indicated that they would shop at FMs more often (Figure 1), and that the FM ambience would improve (Figure 2), if more farmers were present.

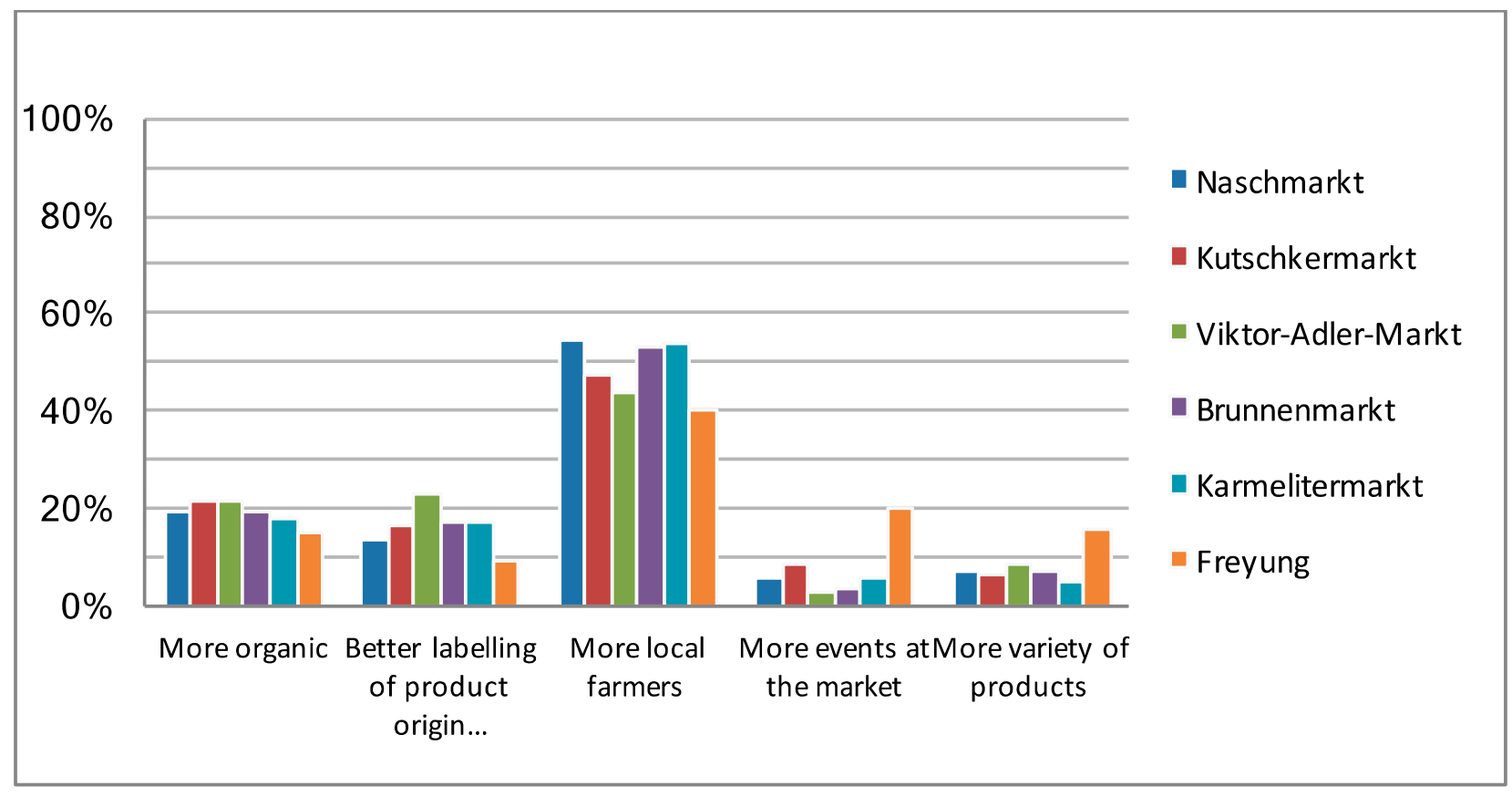

Figure 1. The percentage of consumers answering: What would make you shop more often at the FMs? At the six different markets examined in Vienna. 


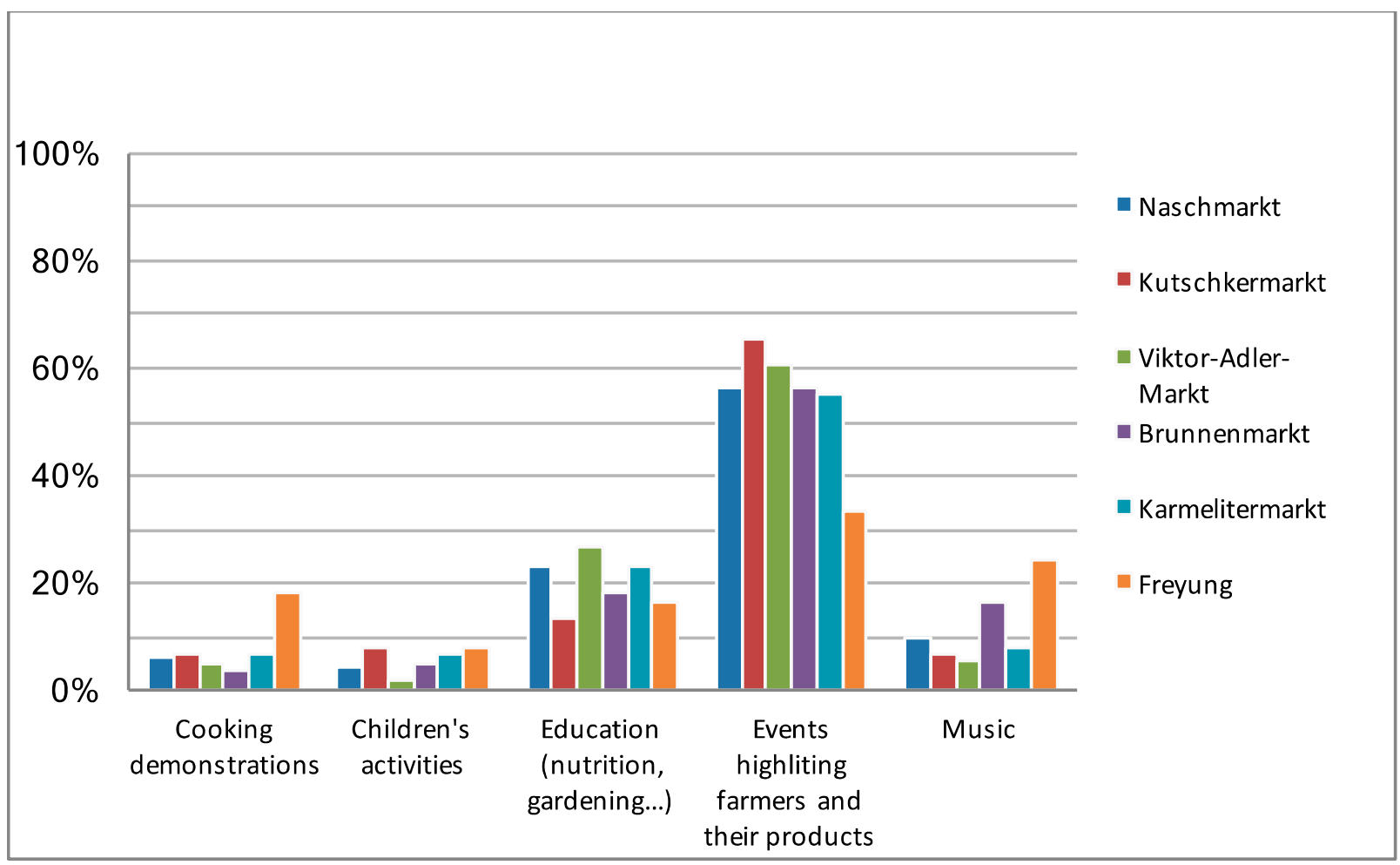

Figure 2. The percentage of consumers answering: What would improve the ambience at the FMs? At the six different markets examined in Vienna.

Longer and more flexible hours were attractive to FM consumers particularly at markets known to be frequented more by families-i.e., Karmelitermarkt and Kutschkermarkt, and the specialty organic market, due to its unique purpose attracting consumers from other neighborhoods.

It is also noteworthy that there was less interest in community building and ambience related activities. Statements were taken during conversations with dot survey participants, in which some consumers felt the markets did not have enough space to add other activities, or did not understand the point of such activities.

Although most Viennese FMs are well attended on Saturdays, a smaller percent of FM consumers would also consider purchasing during the week. They suggested more practical opening hours (after working hours); production transparency; and, information describing producers and products. Recognizing a lack of actual producers, well-informed consumers often asked: "Where are the farmers?" These concerns question the Viennese definition of a farmers market. Managers and farmers informed us that many consumers are so eager to support farmers that they assume their contemporary values are considered within FM structure and functions-often overlooking or taking at face value enterprising vendors (some resellers assume the position, through props or mannerisms, of a farmer). The modern values and changing practices demonstrated through consumers emphasizes the challenges within Viennese FMs to align values among participants.

\section{Discussion}

\subsection{FMs Caught in a Crossroads}

As the trend of urbanization continues, so does the pressure on existing food system change. In Vienna and presumably in other large, regulated urban systems, FM participants illustrate contemporary demands, yet governance has not yet caught up, leaving an area of potential largely in waiting. As front-runners of AFSs, FMs can offer alternatives to conventional ways of food procurement. However, embedded in a system of divergent values, the Viennese municipal FMs have yet to reach their potential as contributors to their 
urban alternative food system. The governance structures, executed by the Market Bureau and its subsequent management, follow a traditional FM approach valuing accessible food procurement, safety and hygiene, supported by a hierarchical governance system. Instead, many farmer/vendor and consumer values reflect additional, alternative values of ecological, social and economic sustainability. Additionally, many farmers/vendors following traditional values and practices believe that they will be the last generation at the markets. These differing values, upcoming changes and the challenges resulting from the dichotomy of values illustrated above, confirm our hypothesis: that misaligned values hinder the Viennese FMs participation in their AFSs and ultimately the resilience of their respective food system.

Faced with the growing misalignment between the existing and the actual FM values and practices and the FMs structures and functions, illustrated above, Viennese FMs are at a crossroads: they must either embrace change and adapt to the modern moment or risk losing the support of consumers and farmers who value direct marketing, local and ecological products, and farmer support. Applying the categories purpose, governance and participant community, below we discuss the potential for value alignment among participants and FM structures and functions to improve the conditions of Viennese FMs and their ability to contribute to AFS. The subsequent suggestions provide a roadmap for how the Viennese FMs, other municipally governed metropolitan FMs, and other alternative food movements might respond to the changing values and practices of their participants.

\subsection{Towards Shared Values}

At a farmers market, an emphasis on values and practices often contributes to or stems from a purpose, whether explicit or implicit. A shared purpose among FM participants informs its function. It allows for clearly communicated values important to a market and its participants. Once these values have been decided upon-whether at the governance level or collectively with its participants - said values can be practiced, advertised and shared. When values have been aligned, the practices that are both encouraged and spontaneously occur, ultimately affect a market's longevity and authenticity challenges.

To begin to align values and practices of both FM participants and its respective structures and functions, a clear purpose is essential. Such a purpose strengthens a farmers markt community and increases purchases [42], ultimately amassing farmer support and reinforcing its contribution to its AFS. A purpose often highlights what consumers and farmers value and the sharing and creation of those values within the market. It can however, solely or additionally reflect the values of the governance system, which can differ from the other participants. A governance system often dictates or facilitates a farmers market structure and its function through its management and through adhering to a purpose and mission statement.

Currently, Viennese FM rules and practices principally reflect the values stemming from managerial and regulatory priorities. Management focuses on providing consumers with a safe and hygienic means to procure groceries, which many see as an outdated purpose. The contrasting values of consumers and most farmers, and the belief that traditional farmers will not be replaced in Vienna, suggest a need for more flexible and collaborative governance system highlighting specific purposes.

Betz and Farmer [43] show a correlation between FM governance and consumer type, consumer attendance, and satisfaction of participants-in other words, the way a farmers market is run impacts its participants. In the Viennese context, vendors and market managers rarely link FMs with AFSs, despite evidence that governance structures that recognize and promote the role and synergies of FMs and AFSs can contribute to their future success [28]. This is illustrated by the lack of integration of diverse groups of farmers (or increased integration of actual farmers) and products at the markets, and by the fact that their potential as social innovators and educators of sustainable food pathways and other related topics is not yet significantly employed. 
Governance changes are needed within the Viennese FMs for them to become more impactful and to actively participate in their respective AFS: " . . understanding how the governance system and structure create a specific culture to the market will help market masters, boards, and local food advocates better understand and plan on how to reach potential non-participants ..." ([43] p. 12). Managers are aware of the consequences of being bound in time and duties related to governance beyond solely the FMs and regulations explicitly preventing marketing and advertising. However, they do not feel responsible for such management duties, and due to the heavily bureaucratic municipal system in which they are embedded, they do not expect any change in the near future.

With a common FM purpose comes the opportunity to build a community and organize around shared beliefs: " ... the farmer's markets that contribute the most to local food system development are those organized and conducted with more deliberate community development intent" ([28] p. 81). Each FM in Vienna is unique; neighborhoods are diverse and vary from district to district (likely in other metropolitan areas as well). This suggests a varied set of values and interests of actual and potential participants. By not promoting the alternativeness of FMs, the supportive functions, such as community organizing, education, and non-economic engagement valued by contemporary consumers, are largely missing from Viennese markets.

\subsection{Areas of Priorities}

A shift to a more modern market governance-one that prioritizes a shared mission-could improve value alignment within its participant community and ultimately the contribution of the FMs to the Viennese sustainable and alternative food system. If each FM in Vienna were to individually decide on a purpose, and to revisit those purposes over time, the markets would be able to invest in a future and share values important to their immediate community and neighborhoods. Creating a common and public purpose would clearly discern the FMs from their respective public markets. This would create opportunities for advertising and distinguishing producers, and differentiate the FMs from each other, from the public markets, and supermarkets. As mission-oriented FMs, they could cater to their immediate neighborhoods, farmer/vendors and consumer base. Their distinct purposes would then inform decisions on function and structures of the market, supporting the values and practices currently sought after.

Managers might facilitate this shift by first understanding the different practices and values of its participants and the FM's surrounding community. This would ideally take place with a variety of participant input, allowing managers to improve value generation, and cultivate an alternative consumption community. To ensure that the uniqueness of each market and its participants would be considered, such purposes could be defined within and by the immediate neighborhoods and FM participants. These participants together could reflect, as suggested from Betz ([43] p. 11) "... how policies, procedures, and activities facilitated by the market may impact (1) which consumers attend the market, (2) motives among those who attend the market, and (3) satisfaction outcome levels among market participants."

Such specific knowledge of a market and its participants could lead to supportive market structures and functions both for farmer/vendors and consumers. Depending on the needs of farmer vendors and consumers, market specific initiatives could be elaborated. Our results indicate that such supportive initiatives in the Viennese case might include an incentive program to encourage more farmer participation at all of the markets and farmers with more variety-especially at the Viktor-Adler Market, the Naschmarkt and the organic Freyung Market; offering a mid-week market that is open late to reflect modern family working hours; manager communication and advertisement via social media or a community booth; and addressing logistical impediments such as vendor parking, on-site storage, and overall product diversity (See: [19]). Such concrete actions can positively change dwindling rural-urban interactions by making the FMs more attractive for farm- 
ers through supportive logistics, but also for consumers looking for a "connection" to "real farmers".

Participatory governance, whether through decision making or definition of a purpose, could be a process of continuous social and collaborative learning that fosters FM participants to integrate the wider community and create knowledge and values together. It could encompass the possible place-based, alternative consumption community of each FM and address social justice concerns linked with re-localization, important to AFSs. Therefore, it is important-as Viennese FMs move towards value alignment between and among its participants - that those participants are accurately identified and engaged appropriately in a farmers market's explicit purpose.

Atmosphere is also important in bringing a community together. However, aside from the occasional live music, market-level practices aimed at promoting community, are unusual in Vienna, and dot survey results showed little consumer understanding towards community building importance at FMs. Managers could both bolster ambience and better represent consumers by recapitulating shared values through marketing, education, events, better signage and transparency. Such practices might include showcasing producers (connecting to consumer motivations discovered through the dot survey), distinguishing individual market characteristics, offering samples, promotion of local, like-minded businesses, or building an informed and engaged community [27]. This would distinguish the FM portion of the public market, and enhance farmer and consumer connections thereby increasing farmer participation and directly contributing to their respective AFS. Re-sellers could also contribute to their AFS by creating trust with their consumers in their connections and transparency with diverse farmers/producers.

If the governance system is unable to adapt to the alternative values and practices favored by many participants, other forms of organizing and synergies exist. These forms may represent how two divergent value systems can positively coexist. As illustrated above, the creation of an additional form of governance, an association-with more transparent and participatory tactics - may lead to a better understanding of each market and active ways to react and respond to participant values and practices. This might include not only vendors and farmers, but community members with more time than farmers to invest in activities to enhance and ensure value alignment. Additionally, Lutz et al. [56] highlighted benefits of farmer cooperation as a means for AFS creation. Cooperation between farmers and between farmers and public market vendors can help develop a vibrant community without formal organization from the Market Bureau. The creation of a farmers market association or internal organization among farmers, consumers or interested organizations with similar values could update rules or develop common practices.

\subsection{Greater Integration of Viennese FMs within AFSs}

Austria, and particularly Vienna, mirrors numerous other countries and metropolitan areas sharing similar goals of strengthening their AFSs as one of many pathways towards sustainability. As the Austrian government strives to support UN Sustainable Development Goals (SDGs), a tangible start would be to orient their markets (and other AFS practices) to reflect some of these goals. Many FM participants hold some of these SDGs as core to their personal values or associated organizational missions.

Specific policy recommendations include highlighting the broader services that FMs can provide. For example, viewing FMs as a type of regional development tool within Austria's agriculture policy could strengthen rural and urban partnerships as well as shift the existing FM purpose away from procurement, towards more social, ecological and cultural emphases. Moreover, as contemporary FMs are often seen as spaces of education, policy toward public health/environment goals could both support FMs and be reinforced through community booths focusing on related community issues and education. Finally, FMs and other direct marketing examples can be flexible and adaptable in times of disruption such as COVID-19 (See: [2,57]). Therefore, additional policy support for 
direct marketing outlets in the current food system would be advantageous both for better integration of FMs within AFSs, but also in contributing to Viennese food security goals.

It is clear that priorities must be set to achieve resilience of the current food system, particularly in an urban setting. Contemporary FMs exhibit social organization and collaborative governance methods, which succeed in value alignment among participants. They create place-based communities of alternative consumption and can result in perpetuated values. These forms of value creation and subsequent practices are extremely potent in mitigating sustainability inhibitors. Although a small representation of many possible alternatives to the current dominant food system, the way a farmers market is structured and functions and responds to and creates values and practices can be improved upon, replicated and amplified among and between alternative movements.

\section{Conclusions}

This paper examines the contribution of value alignment and associated practices to alternative food systems using the case of the Viennese farmers markets in Austria. The current path of the Viennese FMs, with a traditional function of food procurement and safety, both perpetuate and are perpetuated by an inflexible, unreflexive structure. Indicative of this, the current Viennese FM governance system cannot support the contemporary FM movement and many of its participants and subsequent values. We argue that without aligning values, Viennese FMs - or other similar FMs - may lose face with their patrons, particularly as an alternative practice to the current industrialized food system (See: [7]). Suggested here is the need to align FM structures and functions with respective values and practices, which can help smooth this transition and become one pathway among others towards food system resilience and sustainability.

We have argued the importance of attention to shared values and practice among FM purpose, governance and participants. These shared values form the basis of the function in which alternative governance and participants come together to learn, organize and collaborate towards a sustainable future and can be applied to other forms of AFSs as well. Especially in Europe, many metropolitan government systems are over-bureaucratized, delaying efficient and effective communication and collaboration. Such systems are overburdened by regulations and department specialization, making change difficult and lengthy. In this sense, the development of resilient urban food requires processes of exploring synergies and making priorities. The case of Viennese FMs illustrates that the governance system-currently perpetuating antiquated FM purposes and functions-struggles to or even must ignore changes in consumer and vendor values and practices because they lack funds, time, or space to consider changes. In other words, their defined function does not encompass found contemporary values. Their present trajectory could continue, predicated on functioning as spaces of food procurement. However, these FMs could establish themselves as a community that supports alternative food and farming networks. Elsewhere, the latter approach has contributed to a critique of our current food system and a resurgence of FMs that build an informed consumer base and new food initiatives. Either way, the challenges identified are inextricably linked to the existing governance structures and perceptions of FM functions.

In order to promote more alternatives to the dominant Viennese food system, to support farmers, and in Schermer's [13] words 'contribute to new food initiatives', FMs in Vienna must be acknowledged as more than a colloquialism. Instead, they could be recognized as alternative markets that harbor actual farmers and which practice and share values that support them. They must become distinguishable as farmers markets and develop a strong and informed community of managers, vendors and consumers. If this does not occur, consumers and farmers may turn elsewhere.

With the current COVID-19 pandemic and the mounting threat of climate change, there has arguably never been a more pressing time in recent history to inspect the current food system. Given their urban nature, food systems have the unique ability to both perpetuate but also address socio-ecological emergencies. Therefore, examining components of local 
urban food systems and their impacts on local and global sustainability is one place to begin. Acknowledging the further ecological and social benefits of AFSs-and FMs in particular-and improving upon their pitfalls is a step in achieving a resilient and decentralized food supply system.

Supplementary Materials: The following are available online at https: / www.mdpi.com/article / 10.3390 / su13158327/s1, Dot-survey Questions S1.

Author Contributions: Conceptualization, M.K. and R.P.; methodology, M.K. and J.B.; validation, M.K. and J.B. formal analysis, M.K.; interviews M.K.; resources, M.K.; data curation, M.K.; writing—original draft preparation, M.K.; writing—-review and editing, M.K., J.B., R.P. and B.F.; visualization, M.K.; supervision, J.B. and B.F.; funding acquisition, M.K. All authors have read and agreed to the published version of the manuscript.

Funding: This research received no external funding.

Institutional Review Board Statement: Not applicable.

Informed Consent Statement: Informed consent was obtained from all subjects involved in the study. Data Availability Statement: Not applicable.

Acknowledgments: The publication of this article in an Open Access journal was supported by Open Access (OA) Publishing Fund of the University of Natural Resources and Life Sciences, Vienna. The Dot-Survey data collection was supported by Priska Pollak.

Conflicts of Interest: The authors declare no conflict of interest.

\section{References}

1. Maye, D.; Duncan, J. Understanding sustainable food system transitions: Practice, assessment and governance. Sociol. Rural. 2017, 57, 267-273. [CrossRef]

2. Marusak, A.; Sadeghiamirshahidi, N.; Krejci, C.C.; Mittal, A.; Beckwith, S.; Cantu, J.; Morris, M.; Grimm, J. Resilient regional food supply chains and rethinking the way forward: Key takeaways from the COVID-19 pandemic. Agric. Syst. 2021, $190,103101$. [CrossRef]

3. Carlisle, L. Audits and agrarianism: The moral economy of an alternative food network. Elem. Sci. Anthr. 2015, 3, 000066. [CrossRef]

4. Szmigin, I.; Maddock, S.; Carrigan, M. Conceptualising community consumption: Farmers' markets and the older consumer. Br. Food J. 2003, 105, 542-550. [CrossRef]

5. Moore, O. Understanding postorganic fresh fruit and vegetable consumers at participatory farmers' markets in Ireland: Reflexivity, trust and social movements. Int. J. Consum. Stud. 2006, 30, 416-426. [CrossRef]

6. Alrøe, H.F.; Kristensen, E.S. Why have basic principles for organic agriculture?... and what kind of principles should they be? Ecol. Farming 2004, 36, 27-30.

7. Edwards, F. Alternative food networks. In Encyclopedia of Food and Agricultural Ethics; Springer: Berlin/Heidelberg, Germany, 2016; pp. 1-7.

8. Carlson, L.; Bitsch, V. Solidarity: A key element in alternative food networks. Proc. Food Syst. Dyn. 2018, $261-270$.

9. Berti, G.; Mulligan, C. Competitiveness of small farms and innovative food supply chains: The role of food hubs in creating sustainable regional and local food systems. Sustainability 2016, 8, 616. [CrossRef]

10. Figueroa-Rodríguez, K.A.; Álvarez-Ávila, M.d.C.; Hernández Castillo, F.; Schwentesius Rindermann, R.; Figueroa-Sandoval, B. Farmers' market actors, dynamics, and attributes: A bibliometric study. Sustainability 2019, 11, 745. [CrossRef]

11. Gallardo, R.K.; Olanie, A.; Ordóñez, R.; Ostrom, O. The use of electronic payment machines at farmers markets: Results from a choice experiment study. Int. Food Agribus. Manag. Rev. 2015, 18, 79-103.

12. Schermer, M. The Decline of Farmers Direct Marketing in Austria: Consequences and counter strategies. In Proceedings of the 8th European IFSA Symposium, Clermont-Ferrand, France, 6-10 July 2008; pp. 211-220.

13. Schermer, M. From "Food from Nowhere" to "Food from Here": Changing producer-consumer relations in Austria. Agric. Hum. Values 2015, 32, 121-132. [CrossRef]

14. Källström, H.N.; Ljung, M. Social sustainability and collaborative learning. AMBIO A J. Hum. Environ. 2005, 34, 376-382. [CrossRef]

15. De La Pradelle, M. Market Day in Provence; University of Chicago Press: Chicago, IL, USA, 2006.

16. Vecchio, R. Local food at Italian farmers' markets: Three case studies. Int. J. Sociol. Agric. Food 2010, 17, 122-139.

17. Pyle, J. Farmers' markets in the United States: Functional anachronisms. Geogr. Rev. 1971, 61, 167-197. [CrossRef]

18. Mayo, J.M. The american public market. J. Archit. Educ. 1991, 45, 41-57. [CrossRef] 
19. Wien, K.d.S. MA 59 Prüfung der Wirtschaftlichkeit der Wiener Märkte in den Jahren 2003 bis 2006: Tätigkeitsbericht 2007; MA 59: Wien, Austria, 2007; pp. 1-51.

20. Giampietri, E.; Koemle, D.; Yu, X.; Finco, A. Consumers' sense of farmers' markets: Tasting sustainability or just purchasing food? Sustainability 2016, 8, 1157. [CrossRef]

21. Pascucci, S.; Cicatiello, C.; Franco, S.; Pancino, B.; Marinov, D.; Davide, M. Back to the future? Understanding change in food habits of farmers' market customers. Int. Food Agribus. Manag. Rev. 2011, 14, 105-126.

22. Byker, C.; Shanks, J.; Misyak, S.; Serrano, E. Characterizing Farmers' Market Shoppers: A Literature Review. J. Hunger. Environ. Nutr. 2012, 7, 38-52. [CrossRef]

23. Brown, C.; Miller, S. The impacts of local markets: A review of research on farmers markets and community supported agriculture (CSA). Am. J. Agric. Econ. 2009, 90, 1298-1302. [CrossRef]

24. Alkon, A.H. From value to values: Sustainable consumption at farmers markets. Agric. Hum. Values 2008, 25, 487-498. [CrossRef]

25. Garner, B.; Ayala, C. Consumer supply-chain demands and challenges at farmers' markets. Br. Food J. 2018, 120, 2734-2747. [CrossRef]

26. Payne, T. US Farmers Markets, 2000: A Study of Emerging Trends; US Department of Agriculture, Marketing and Regulatory Programs, Agricultural Marketing Service, Transportation and Marketing Programs, Marketing Services Branch: Washington, DC, USA, 2002.

27. Smithers, J.; Lamarche, J.; Joseph, A.E. Unpacking the terms of engagement with local food at the farmers' market: Insights from Ontario. J. Rural. Stud. 2008, 24, 337-350. [CrossRef]

28. Gillespie, G.; Hilchey, D.L.; Hinrichs, C.C.; Feenstra, G. Farmers' markets as keystones in rebuilding local and regional food systems. In Remaking the North American Food System: Strategies for Sustainability; Hinrichs, C., Lyson, T., Eds.; University of Nebraska Press: London, UK, 2007; pp. 65-83.

29. Johnson, A.J. 'It's more than a shopping trip': Leisure and consumption in a farmers' market. Ann. Leis. Res. 2013, 16, 315-331. [CrossRef]

30. Sadler, R.C.; Clark, M.A.; Gilliland, J.A. An economic impact comparative analysis of farmers' markets in Michigan and Ontario. J. Agric. Food Syst. Community Dev. 2013, 3, 61. [CrossRef]

31. Kelly, M. Owning Our Future: The Emerging Ownership Revolution; Berrett-Koehler Publishers: Oakland, CA, USA, 2012.

32. Maye, D.; Kirwan, J. Alternative food networks. Sociol. Agric. Food 2010, 20, 383-389.

33. Coster, M.; Kennon, N. New Generation Farmers' Markets in Rural Communities; Rural Industries Research and Development Corporation: Canberra, Austrilia, 2005.

34. Gantla, S.; Lev, L. Farmers' Market or Farmers Market? Examining How Market Ownership Influences Conduct and Performance. J. Agric. Food Syst. Community Dev. 2016, 6, 49-63. [CrossRef]

35. Alkon, A.H. Black, White, and Green: Farmers Markets, Race, and the Green Economy; University of Georgia Press: Athens, GA, USA, 2012; Volume 13.

36. Dodds, R.; Holmes, M.; Arunsopha, V.; Chin, N.; Le, T.; Maung, S.; Shum, M. Consumer choice and farmers' markets. J. Agric. Environ. Ethics 2014, 27, 397-416. [CrossRef]

37. Hinrichs, C.C. Embeddedness and local food systems: Notes on two types of direct agricultural market. J. Rural. Stud. 2000, 16, 295-303. [CrossRef]

38. Lawson, R.; Guthrie, J.; Cameron, A.; Fischer, W.C. Creating value through cooperation: An investigation of farmers' markets in New Zealand. Br. Food J. 2008, 110, 11-25. [CrossRef]

39. Malagon-Zaldua, E.; Begiristain-Zubillaga, M.; Onederra-Aramendi, A. Measuring the economic impact of farmers' markets on local economies in the basque country. Agriculture 2018, 8, 10. [CrossRef]

40. Wolfram, M. Conceptualizing urban transformative capacity: A framework for research and policy. Cities 2016, 51, 121-130. [CrossRef]

41. Mainville, D.Y. Foundations for a successful farmers market. Va. Coop. Ext. 2010, 448-502, 1-15.

42. Stephenson, G.O. Farmers' Markets: Success, Failure, and Management Ecology; Cambria Press: Amherst, NY, USA, 2008.

43. Betz, M.E.; Farmer, J.R. Farmers' market governance and its role on consumer motives and outcomes. Local Environ. 2016, 21, 1420-1434. [CrossRef]

44. Smithers, J.; Joseph, A.E. The trouble with authenticity: Separating ideology from practice at the farmers' market. Agric. Hum. Values 2010, 27, 239-247. [CrossRef]

45. Tumlin, O.; Farmers' Market Relations. Chancellor's Honors Program Projects. 2020. Available online: https://trace.tennessee. edu/utk_chanhonoproj/2339 (accessed on 13 October 2020).

46. Kassai, M.; Kaspar, J.; Deif, A.; Smith, H. Exploring farmers markets as a temporary cluster to improve local food economy. Br. Food J. 2018, 120, 1844-1858. [CrossRef]

47. Sadler, R.C. Strengthening the core, improving access: Bringing healthy food downtown via a farmers' market move. Appl. Geogr. 2016, 67, 119-128. [CrossRef]

48. Onyango, B.; Govindasamy, R.; Alsup-Egbers, C.M. Uncovering success attributes for direct farmers' markets and agri-tourism in the Mid-Atlantic Region of the United States. Int. Food Agribus. Manag. Rev. 2015, 18, 63-78.

49. Mount, P. Growing local food: Scale and local food systems governance. Agric. Hum. Values 2012, 29, 107-121. [CrossRef] 
50. Klimek, M.; Bingen, J.; Freyer, B. Metropolitan farmers markets in Minneapolis and Vienna: A values-based comparison. Agric. Hum. Values 2018, 35, 83-97. [CrossRef]

51. IFOAM. Principles of Organic Agriculture. Available online: http://www.ifoam.org/en/organic-landmarks/principles-organicagriculture (accessed on 30 August 2020).

52. Lev, L.; Brewer, L.J.; Stephenson, G.O. Tools for Rapid Market Assessments; Oregon State University, Extension Service: Corvallis, OR, USA, 2008.

53. Bousska, H.W. Wiener Märkte; Sutton Verlag: Erfurt, Germany, 2012.

54. Sicherheit, M.S.L. Geschichte der Markt- und Lebensmittelaufsicht. Available online: https://www.wien.gv.at/freizeit/ einkaufen/maerkte/geschichte/marktamt.html (accessed on 5 June 2019).

55. Jaklin, U.; Kummer, S.; Milestad, R. Why Do Farmers Collaborate with a Food Cooperative? Reasons for Participation in a Civic Food Network in Vienna, Austria. Int. J. Sociol. Agric. Food 2015, 22, 41-61.

56. Lutz, J.; Smetschka, B.; Grima, N. Farmer Cooperation as a Means for Creating Local Food Systems-Potentials and Challenges. Sustainability 2017, 9, 925. [CrossRef]

57. Kolodinsky, J.; Sitaker, M.; Chase, L.; Smith, D.; Wang, W. Food Systems Disruptions. J. Agric. Food Syst. Community Dev. 2020, 9, 5-8. 